Overcoming the Odds 


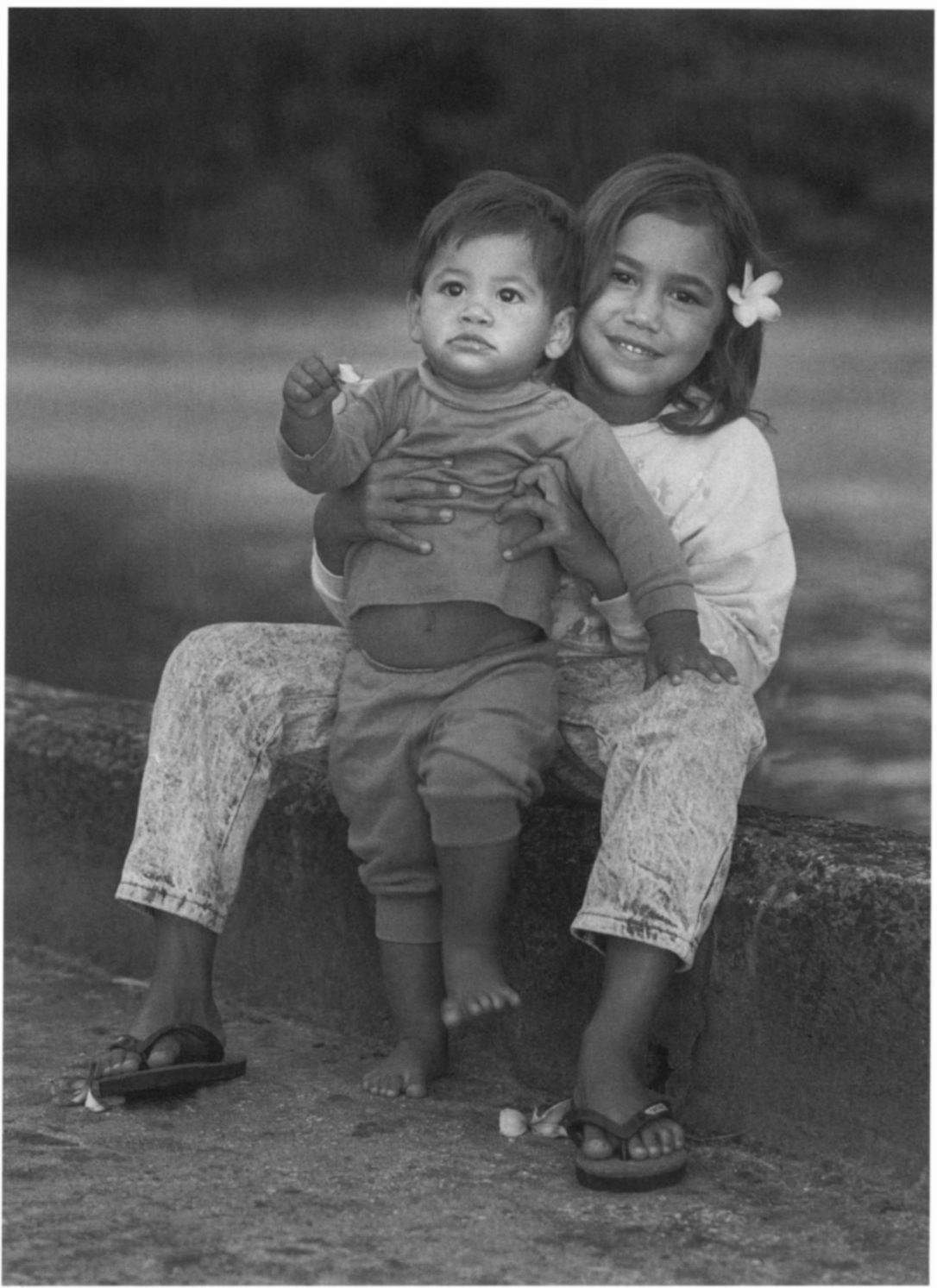




\section{Overcoming the Odds}

\section{High Risk Children \\ from Birth to Adulthood}

Emmy E. Werner and

Ruth S. Smith

Cornell University Press Ithaca and London 


\section{Copyright $\odot 1992$ by Cornell University}

All rights reserved. Except for brief quotations in a review, this book, or parts thereof, must not be reproduced in any form without permission in writing from the publisher. For information, address Cornell University Press, Sage House, 512 East State Street, Ithaca, New York 14850.

First published 1992 by Comell University Press First printing, Cornell Paperbacks, 1992

We gratefully acknowledge the permission to reprint in the Introduction the first stanza of poem \#657 from The Complete Poems of Emily Dickinson, edited by Thomas H. Johnson. Copyright 1929 by Martha Dickinson Bianchi. Copyright () renewed 1957 by Mary L. Hampson. By permission of Little, Brown and Company. Reprinted by permission of the publishers and the Trustees of Amherst College from The Poems of Emily Dickinson, edited by Thomas H. Johnson, Cambridge, Mass.: The Belknap Press of Harvard University Press, Copyright 1951, (C) 1955, 1979, 1983 by the President and Fellows of Harvard College.

Library of Congress Cataloging-in-Publication Data

Werner, Emmy E., 1929-

Overcoming the odds : high risk children from birth to adulthood / Emmy E. Werner and Ruth S. Smith.

p. $\mathrm{cm}$.

Includes bibliographical references and index.

ISBN 0-8014-2584-0 (alk. paper),-ISBN 0-8014-8018-3 (pbk. : alk. paper)

1. Children-Hawaii-Kauai-Longitudinal studies. 2. Socially

handicapped children-Hawaii-Kauai-Longitudinal studies. 3. Life

change events-Hawaii--Kauai-Longitudinal studies. I. Smith, Ruth

S., 1923- II. Title.

HQ792.U5W39 1992

$371.96^{\prime} 7^{\prime} 0996941-\mathrm{dc} 20$

$91-23415$

Cornell University Press strives to utilize environmentally responsible suppliers and materials to the fullest extent possible in the publishing of its books. Such materials include vegetable-based, low-VOC inks and acid-free papers that are also either recycled, totally chlorine-free, or partly composed of nonwood fibers.

Paperback printing $\quad 10 \quad 9 \quad 8 \quad 8 \quad 7 \quad 6 \quad 5$ 
To Stanley and Earl-with much aloha 
